\title{
Getting Real with Rouse and Heidegger
}

Jeff Kochan

Zukunftskolleg, University of Konstanz

\begin{abstract}
Joseph Rouse has drawn from Heidegger's early philosophy to develop what he calls a "practical hermeneutics of science." With this, he has not only become an important player in the recent trend towards practice-based conceptualisations of science, he has also emerged as the predominant expositor of Heidegger's philosophy of science. Yet, there are serious shortcomings in both Rouse's theory of science and his interpretation of Heidegger. In the first instance, Rouse's practical hermeneutics appears confused on the topic of realism. In the second instance, Rouse suppresses Heidegger's distinction between existence and essence, and hence fails to grasp the latter's corollary distinction between scientific research and everyday practice. I argue that, by accepting a correction in his interpretation of Heidegger, Rouse would find the means to resolve the debilitating tensions in his stance towards realism.
\end{abstract}

\section{Introduction}

Joseph Rouse is well-known as an early advocate for the "practice turn" in the philosophy of science. The impact of this turn on the current study of science has been deep and far-reaching. Not only has the philosophical study of scientific practice provided crucial conceptual support for a nowmaturing body of literature on scientific experimentation, the notion of

An earlier version of this paper was read to the Department of Philosophy at the University of Alberta, and I thank audience members for their many helpful comments. Thanks also to Martin Kusch for his encouragement and criticism of an earlier draft. The detailed criticism of an anonymous reader also proved enormously helpful. Research for the paper was funded, in part, by the Social Sciences and Humanities Research Council of Canada. The paper was completed during an extended research stay at the University of Basel, and I especially thank Hans Bernhard Schmid for his generous hospitality in this regard.

Perspectives on Science 2011, vol. 19, no. 1

(C)2011 by The Massachusetts Institute of Technology 
practice has itself served as a key gathering point around which the interdisciplinary field of science and technology studies (STS) has taken shape and acquired influence. In addition to numerous essays, Rouse has made three book-length contributions to these developments (Rouse 1987, 1996, 2002). My focus in this essay will be set largely on the earliest, and arguably most influential, of these three volumes, Knowledge and Power (1987), as well as on some of Rouse's shorter contributions from the 1980s. The reasons for this are entirely pedestrian. My interest is directed towards the soil in which Rouse's early ideas about science germinated and broke through to the surface.

A substantive element in Rouse's early development was his engagement with the philosophy of Martin Heidegger. In this essay, I will examine the consequential use to which Rouse puts Heidegger's work. Indeed, as will be discussed in section 2, Rouse gathers together two threads from Heidegger's early philosophy - the first, a hermeneutics of experience, the second, a phenomenology of practice-and fashions them into a "practical hermeneutics" which provides the backdrop for his philosophy of scientific practice. In section 3, I go on to consider Rouse's claim that his practical hermeneutics of science might successfully transcend the seemingly intractable dialectic of realism and antirealism so well known and vexing for philosophers of science. A closer examination of Heidegger's own position on this topic turns up a crucial difference between Rouse and Heidegger: whereas Rouse attempts to collapse the difference between an entity's existence and its meaning, Heidegger keeps the two separate. As a result, unlike Rouse, Heidegger can allow that entities exist without also being the subjects of interpretation. On this basis, I suggest that Heidegger can accommodate the core realist doctrine of independent existence, and hence the natural intuition that scientists "get at the real."

In section 4, I argue that Rouse's failure to accept the realist doctrine of independent existence introduces a debilitating tension into his account of scientific practice. While Rouse's practical hermeneutics explicitly rejects the doctrine of independent existence, many passages in his work tacitly rely upon that very doctrine for their intelligibility. I thus suggest that Rouse, despite his claims to the contrary, is a kind of realist after all, albeit a somewhat confused one. At the heart of this confusion is Rouse's failure to distinguish the minimal realist doctrine that entities exist independently of our interpretations of them from the more ambitious realist doctrine, typical of scientific realists, that the determinate properties of such entities also exists independently of our interpretations. Because Rouse does not distinguish between these two doctrines, he unwittingly rejects the former along with the latter. Heidegger, in contrast, rejected the for- 
mer but not the latter. On this basis, he can be plausibly construed as a minimal (not a scientific) realist. ${ }^{1}$

In section 5, I probe more deeply into the differences separating Rouse and Heidegger. I argue that these differences turn on two related themes in Heidegger's work. The first is Heidegger's insistence that the meaning of the term "being" should be a basic topic for philosophical enquiry rather than a self-evident concept which is simply taken for granted. Rouse takes the meaning of the term "being" (and its cognates) for granted, and hence denies himself the benefits of Heidegger's observation that "being" is a polysemic term with at least two distinct meanings: existence and essence. Ignorance of this distinction helps explain Rouse's errant assimilation of existence to meaning. The second theme is Rouse's firm rejection of Heidegger's distinction between everyday practice and scientific research. Rouse instead urges a homogenous conception of practice which recognises no consequential difference between actions in the everyday and scientific realms. I show that Rouse's criticism of Heidegger's distinction flies wide of the mark, and so he fails to convincingly close the gap between science and everyday life.

In section 6, I argue that, by introducing Heidegger's distinction between existence and essence into Rouse's practical hermeneutics of science, it becomes possible to resolve the practical tensions debilitating Rouse's account of scientific practice. This move will also allow Rouse to join Heidegger in accommodating a minimal realism which can support the basic claim that science gets at the real. The price Rouse must pay for this, however, is the abandonment of his conviction that there is no important difference between everyday and scientific practice. Yet I suggest that Rouse stands to lose much less than he might think in making this concession.

The general goal of this essay is not only to advance the reader's understanding of Rouse's philosophy of scientific practice, but also to provide an interpretation of Heidegger's philosophy of science which might stand as an alternative to Rouse's own. ${ }^{2}$ In recent years, Rouse has arguably emerged as the predominant expositor of Heidegger's philosophy of science, with contributions in several high-level reference works (Rouse

1. Psillos (1999, p. xix) argues that the latter, more ambitious doctrine is "a basic philosophical presupposition of scientific realism." Hacking (1999, p. 83) deliberately disparages this doctrine with the unpleasant name "inherent-structurism," and has defended the former, more minimalist doctrine against the charge of idealism (Hacking 1983, p. 108). Kochan (2008) provides a further discussion of the difference between these two doctrines.

2. For a more comprehensive recent account of Heidegger's philosophy of science, see Glazebrook (1998, 2000a, 2000b, 2001a, 2001b). 
1998, 2005a, 2005b). If, as I contend, there are serious shortcomings in Rouse's presentation of Heidegger, then it would seem only prudent that his authority on this point be challenged and that readers with an interest in Heidegger's philosophy of science be presented with an alternative interpretation which they may find useful in formulating a balanced position of their own.

\section{Rouse's Practical Hermeneutics of Science}

Rouse draws from Heidegger's Being and Time in order to elaborate what he calls a "practical hermeneutics" of science. This position puts a pragmatist spin on traditional hermeneutics with the goal of establishing a fully universalised theory of science adequate not only to the analysis of the human, or "interpretive," sciences, but also to such ostensibly "non-interpretive" natural sciences as physics, chemistry, and biology. Rouse claims, in fact, that all scientific knowledge is the consequence of interpretation, and hence that hermeneutics - as a general theory of interpretation-must serve as the foundation for any comprehensive theory of science.

Hermeneutics began life as a theory of textual interpretation. According to Rouse (1987, p. 42), we approach a text with the assumption that it has a meaning which our interpretations can discover or elucidate. Following Wilhelm Dilthey, Rouse (1987, p. 42) furthermore argues that "many nontextual features of human life, such as actions, tools, social roles, and individual lives, can and should be taken as meaningful in the same way as texts are." Rouse (1987, p. 56) thus distinguishes practical hermeneutics from "theoretical hermeneutics," which he dubs an "epistemological" theory of interpretation. Theoretical hermeneutics is epistemological because it takes the contextualising background of an interpretive act to be comprised exclusively of such cognitive phenomena as theories, beliefs, and values (1987, p. 57). Practical hermeneutics, in contrast, takes this interpretive background to consist in practices, social roles, and equipment (Rouse 1987, p. 60). Rouse credits Heidegger with having initiated this move from theoretical to practical hermeneutics. On this account, the meaning of a thing is "in the world" rather than "in the head" (Rouse 2002b, p. 76). Meanings are, in other words, intrinsic to the entities we encounter within the world.

However, meaning is not itself an entity. It is better described as the way an entity is intelligibly disclosed within the world. Taking Heidegger's Being and Time as his guide, Rouse elaborates this point through a phenomenological analysis of equipment and its use. He writes that "we use equipment, and in this use it acquires an orientation, a focus, a significance, a function" (Rouse 1987, p. 59). Furthermore, such equipment is what it is only within a larger equipmental context $(1987$, p. 60). Rouse 
draws these claims out of the passage in Being and Time where Heidegger writes:

Taken strictly, there "is" no such thing as an equipment. To the Being of any equipment there always belongs a totality of equipment, in which it can be this equipment that it is. Equipment is essentially "something in-order-to ..." ["etwas um-zu ..."]. A totality of equipment is constituted by various ways of the "in-order-to", such as serviceability, conduciveness, usability, manipulability. (Heidegger 1962, p. 97 [68].)

Heidegger argues that the ontological structure of equipment always points towards other equipment. The iteration of such reference constitutes an overall equipmental totality in which any specific piece of equipment can be meaningfully disclosed as what it is. Heidegger (1962, p. 120 [87]) describes this referential totality as "mak[ing] up the structure of the world."

Here, then, we have the basis for Rouse's claim that meaning is intrinsic to entities as they are encountered within the world. This world is structured by a totality of equipmental relations which constitute a field of intelligibility wherein entities might be encountered as meaningful. Heidegger thus emphasises that meaning is "not a property attaching to entities, lying 'behind' them, or floating somewhere as an 'intermediate domain"” (1962, p. 193 [151]). It is on the basis of this account of meaning that Rouse promotes a universal hermeneutics. Because the world as a whole is a meaning-constitutive structure, it turns out that anything which can be within that world, that is, any entity-whether it be a joke or a traffic jam, modus ponens or the Monte Carlo method, a slime mould or a super string - is intrinsically meaningful. Furthermore, because this meaning-world is itself constituted by practices, equipment, and social roles, rather than by beliefs and theories, Rouse argues that universal hermeneutics must be a specifically practical hermeneutics.

Rouse's claim that the world is constituted by practices, equipment, and social roles seems to pose a direct challenge to realism. For, if our practices play a fundamental role in the constitution of the world, then the realist's basic conviction that at least some entities must exist independently of our involvement with them appears hopeless. Indeed, Rouse's position would seem to have more in common with such antirealist doctrines as constructivism than it does with realism. Yet, Rouse argues that his practical hermeneutics of science is a position quite distinct from both re-

3. I will follow the established convention of including the corresponding pagination of the original 1927 German edition of Being and Time in square brackets. 
alism and antirealism. The next section will explore this argument in some detail.

\section{Rouse against Realism and Antirealism}

Rouse (1987, p. 129) argues that his practical hermeneutics can dodge around the central doctrines of both realism and antirealism without also endangering the majority of claims made by contemporary scientists. In laying out this argument, most of his attention goes to realism, and that will also be the main focus here. However, it will be useful to first also consider Rouse's treatment of antirealism.

Rouse limits his discussion of antirealism to two of its more prominent representatives: empiricism and constructivism. His main grievance against empiricism concerns its account of observation. Empiricists maintain that scientific knowledge is ultimately rooted in experience, and they generally think that our most basic beliefs simply "read off" what is presented in experience. When the tomato is visually presented to me as red, I simply "register" this appearance in forming the belief that the tomato is red (cf. Alston 1998, p. 290). Most of our beliefs are not formed in this way, but the empiricist holds that support for more complex types of belief formation can always be traced back to basic perceptual experience. Thus, according to Rouse, the empiricist argues that scientific knowledge is founded on a "pure observation language" which reports the elementary data of raw experience.

Rouse rejects the empiricist's doctrine of a pure observation language. He construes the empiricist's appeal to observation as a misguided attempt to solve the problem of how we gain perceptual access to entities in the external world: observation is meant to bridge the gap between our representations of the world and the world itself (Rouse 1987, pp. 142143). With Rouse's practical hermeneutics, this problem never arises because the radical division of our descriptions of the world from the world itself is simply denied from the start. For Rouse, we are always already in the world, practically involved with our surroundings at the fundamental level of everyday practice.

With this, Rouse closely follows Heidegger's Being and Time. For Heidegger (1962, p. 78 [52]), human existence, or what he calls Dasein, has the essential state of "Being-in-the-world." This state is consequentially different from the better-known state of being-a-subject, with its corollary concept of the world as being-an-object. Indeed, Heidegger (1962, p. 87 [60]) emphasises that "subject and Object do not coincide with Dasein and world." On this model, observation is an action within a world where Dasein always already finds itself, rather than an action directed towards a world which Dasein first must encounter as an object sep- 
arate from itself. As Heidegger (1962, p. 89 [62]) puts it, perception is not a matter of "returning with one's booty to the 'cabinet' of consciousness after one has gone out and grasped it."

It seems clear, then, that Heidegger would, along with Rouse, reject the empiricist doctrine of a pure observation language. Yet Rouse cautions that his own rejection of this doctrine should not be mistaken for an endorsement of constructivism. According to him, the central claim of constructivism is that observation is theory laden. In other words, like Rouse, constructivists reject the notion of a pure observation language, but, unlike Rouse, they do so because they believe that our only access to the world is through theory-laden observation. In fact, Rouse points out that the challenge posed by his practical hermeneutics to theoretical hermeneutics is equally effective against constructivism. With a nod towards Ian Hacking (1983), he argues that scientific research practices have "a life of their own" independent of theory and may thus yield interpretations of the world importantly different from ones laden by theory (Rouse 1987, p. 129). Moreover, Rouse (1987, p. 129) emphasises that, because practical hermeneutics puts the weight on practice rather than on theory, it does not point towards the "apparently idealist implications of constructivism."

Rouse's rejection of both antirealism and idealism may suggest that he instead propounds some form of realism. Yet, as already noted, Rouse strongly resists this suggestion. Indeed, he claims that the standard opposition of realism to antirealism is based on a "serious confusion" (Rouse 1987 , p. 129). Yet, although Rouse follows his criticism of antirealism with a lengthy repudiation of realism, he does not deliver clear and sufficient grounds for the claim that realism and antirealism are, in an important sense, the same kind of doctrine. Such grounds are, however, amply presented in Heidegger's Being and Time. There Heidegger diagnoses the problem common to both realism and antirealism as rooted in a shared assumption that the world is an object to which a subject seeks access. The realist believes that such access can be gained, at least in principle, without implicating the subject's own background of beliefs and cultural dispositions. The antirealist, in contrast, believes that any such access will be

4. Based upon his rejection of both empiricism and constructivism, Rouse naturally also rejects, on two grounds, the "constructive empiricism" of Bas van Fraassen (1980). First, van Fraassen's account is still wedded to the idea that observability is of fundamental philosophical importance to a theory of science. For Rouse (1987, p. 145), practical circumspection is more basic than observation. Second, against van Fraassen, Rouse (1987, p. 145) argues that science does not just construct empirically adequate representations of what exists; rather, it aims to get at the real as it exists independently of our representations. 
necessarily shaped by the subject's background beliefs and culture. In both cases, the problematic is understood in broadly epistemological terms, that is, in terms of whether and how the subject gains knowledge of the world construed as an external object, that is, how it gains access to "reality."

Against this schema, Heidegger (1962, p. 246 [202]) argues that knowledge of reality is "a founded mode of access to the Real." By calling such knowledge "a founded mode of access," he means that it can be broken down and explained in terms of another, more basic level of analysis. This deeper level of analysis is, of course, Heidegger's analytic of Dasein. $\mathrm{He}$ argues that, as long as realists and antirealists take for granted the subject-object ontology which drives their shared epistemological problematic, their respective positions will sink ever more hopelessly into a conceptual quagmire (Heidegger 1962, p. 247 [203]). As a remedy for this predicament, Heidegger (1962, p. 246 [202]) recommends the insight that all access to reality "is founded ontologically upon the basic state of Dasein, Being-in-the-world." In other words, he proposes the dissolution of the subject-object dichotomy into the more basic ontological unity of Dasein's Being-in-the-world. With this, the epistemological problematic driving both realism and antirealism loses its force. Dasein does not struggle for access to the world because Dasein's basic state is to always already be in the world.

There is a subtle but important distinction in Heidegger's solution which warrants special emphasis. His claim that knowledge of reality is a founded mode of access to the real implies that the real might be encountered independently of reality. Here I take "the real" to refer to undifferentiated entities, that is, things which simply exist. As mentioned earlier, Heidegger defines reality as an interpretation of the world in terms of objecthood. Once this interpretation has been taken for granted and comes to dominate Dasein's experience, the entities Dasein encounters within the world will also tend to be experienced as objects (Heidegger 1962, p. 245 [201]). On Heidegger's account, then, "realism" names a doctrine which construes the world ontologically as objecthood, and it is the "objectstructure" of this world which Heidegger calls "reality." When the realist claims to "get at the real," Heidegger argues that she is doing so on the basis of a taken-for-granted conception of entities as structured by reality. On this conception, the nature of the real is determined in advance as objecthood. The central point here is that the realist's concept of reality is not primitive but theory laden. Heidegger's realist deploys a theoretical understanding of the world as an object in relation to a subject. She presupposes, in other words, a subject-object ontology, and from this presupposition flow, Heidegger claims, all of the inevitable paradoxes which 
push towards the apparent absurdities of antirealism. On Heidegger's account, then, the root problem of both realism and antirealism is that they both begin their analyses one level too late. They start at the level of subject and object rather than at the more primitive level of Dasein and world. Insofar as both realists and antirealists rely upon a theoretical conception of the world as reality, they both fail to get at the real in a way which discloses entities in their more fundamental, non-objectival state.

This brief excursus through Being and Time can help illuminate Rouse's claim that the standard opposition of realism to antirealism is based on a serious confusion. As Heidegger explains, far from being opposites, both doctrines share the same root problem. The solution to this problem is not to confront it head-on, but to dig beneath it into an analytic of Dasein as Being-in-the-world. This is the level at which Rouse's practical hermeneutics operates. For Rouse, objects are replaced by equipment, and the problem of the subject's access to reality is resolved in the unity of Dasein's practical engagement in a world of equipment. Hence, Rouse's practical hermeneutics seems well placed to deliver an account of science which is indebted to neither realism nor antirealism. We have already examined Rouse's treatment of antirealism. Let us now turn to his discussion of realism.

Rouse defines realism like this:

Realism is typically construed as the view that scientific theories are true or false depending on whether the objects they describe (including unobserved objects like electrons and quarks) actually exist and have the characteristics the theories ascribe to them. (Rouse 1987, p. 127.)

The first thing to notice about this definition is that Rouse makes truth central to realism. Indeed, he even claims that "realists presuppose a correspondence theory of truth" (Rouse 1987, p. 127). It should come as no surprise, then, that Rouse's strategy for undermining realism involves first rejecting the correspondence theory. He does this by introducing, in its stead, a "deflationary" account of truth (Rouse 1987, p. 141). This has the effect of transforming truth from a metaphysical or epistemological concept into a semantic one. ${ }^{6}$

5. As should be clear, Heidegger's chief historical interlocutor here is Descartes. However, it is worth mentioning that Heidegger also picks on Kant for having uncritically inherited the Cartesian epistemological problematic: "In taking over Descartes' ontological position Kant made an essential omission: he failed to provide an ontology of Dasein. This omission was a decisive one in the spirit [im Sinne] of Descartes' ownmost Tendencies" (Heidegger 1962, p. 46 [24]).

6. The connexion Rouse draws between realism and truth is contentious. Michael 
As Rouse writes, the deflationist insists that all we need to know about truth is contained in the Tarski sentence "Snow is white' is true iff snow is white" (op. cit., pp. 141-42). In other words, anything that can be said using the predicate "is true" can be said just as well without using that predicate. Hence, to say that " $p$ ' is true” is the same as saying more simply that "p." From this it follows that truth predicates do not introduce any new facts about the sentence in question. As a consequence, the deflationist claims that we can get along without a theory of truth, because, as Rouse (1987, p. 147) puts is, "[t]ruth plays no explanatory role." In this way, the deflationary account undercuts the metaphysical doctrine of correspondence. If saying that " $\mathrm{p}$ " is true introduces no new facts, then it certainly does not introduce the fact that " $\mathrm{p}$ " is true because it has the property of corresponding to $p$.

In adopting deflationism, Rouse explicitly follows Arthur Fine. Fine argues that once a deflationary account of truth is accepted there is nothing more to say about scientific truth beyond Tarski's formulation. Both realists and antirealist should toe what he calls the "homely line", accepting the truths of science in the same way one accepts more homely truths in everyday life (Fine 1986, p. 128). Fine dubs this homely approach the "core position," arguing that realists and antirealists can be distinguished by what they add to this position. Realists add an "outer direction," positing an external world and correspondence relation. Antirealists, in contrast, add an "inner direction," espousing the human-dependency of truth, concepts, or explanations (Fine 1986, p. 133). Fine rejects the legitimacy of both additions, insisting that the core position, which he also calls the "natural ontological attitude," says all there is to say about truth.

From this brief description, it should be clear that, unlike Heidegger, Fine makes no attempt to resolve the epistemological problematic motivated by the modern subject-object schema. His "natural ontological attitude" might thus be characterised as an attitude of complacency regarding the issues which trouble realists and antirealists alike. He identifies a "core doctrine" common to both realists and antirealists, but declines to problematize it in the way Heidegger does. It is perhaps not unsurprising, then, that Rouse rejects Fine's complacency. Indeed, he argues that Fine's natural ontological attitude cannot sustain sceptical scrutiny because it includes a fatal weakness: it rules out globally and in advance certain kinds of explanation (e.g., realist, antirealist), but does so on the basis of a global

Devitt (1984, p. 35), for example, has argued that "[r]ealism does not strictly entail any doctrine of truth at all." By espousing a semantic approach to the realism-antirealism debate, Rouse moves close to the position of Michael Dummett. See Dummett (1978, p. xl). Devitt (1984, chpt. 12) responds to Dummett. 
conception of what a philosophical explanation is (Rouse 1988, p. 298). It seems reasonable to infer that the global conception Rouse has in mind here is one underwritten by the subject-object ontology which Fine simply takes for granted, and which Rouse, following Heidegger, abandons. ${ }^{7}$

Unlike Fine, Rouse's main reason for accepting deflationism is his belief that all substantive issues concerning truth reflect more general ontological issues, in particular, the question of "how things have any determinations at all" (Rouse 1987, pp. 147-48). He apparently believes that existence counts as one such determination, and this belief allows him to assimilate existential questions under to the general semantics of the deflationary approach. Indeed, Rouse (1987, p. 161) asserts that existence and truth are similarly related to meaning, and argues on the basis of this assertion that

[j]ust as what is not a sentence in a language is not true-or-false, there is no fact of the matter about whether things that cannot intelligibly be encountered within a meaningful world exist or do not exist. (Rouse 1987, p. 160.)

Rouse takes the insight that no statement can be true (or false) unless it is meaningful, combines it with the further premise that truth and existence have a similar relation to meaning, and concludes that nothing at all can exist (or not exist) unless it is meaningful. From this it follows, on Rouse's account, that meaning and existence are somehow equivalent.

The motivating force behind Rouse's attempted assimilation of existence to meaning is apparently his goal of developing a universal hermeneutics of science. Such a hermeneutics must be able to affirm the existence of such unobservable entities as electrons and positrons. An ability to affirm the existence of such entities would help move Rouse's practical hermeneutics closer to realism. Rouse moves still closer to realism in urging that the existence of electrons and positrons is genuinely theoryindependent. Indeed, he firmly endorses Hacking's famous argument for realism (Rouse 1987, p. 131). Responding to the successful manipulation of sub-atomic particles in the laboratory, Hacking (1983, p. 23) writes: "So far as I'm concerned, if you can spray them then they are real." Spraying subatomic particles is not an act of theory; it is a practical act. Rouse argues that, insofar as practical action proves the existence of these entities, a proof has been given independently of theory. However, he also presses the

7. Trish Glazebrook (2001a, p. 377) points out that, unlike Heidegger, Fine fails to deconstruct the modern subject. Michael Williams (1991, pp. 244-246) argues along lines complementary to those offered here that deflationary accounts of truth are, despite the claims of those who advocate them, vulnerable to epistemic scepticism. 
point that such proof has not also been given independently of practice. Hence, citing the core realist doctrine that entities can exist independently of our theories and practices, Rouse insists that his practical hermeneutics can no more be counted a form of realism than it can a form of antirealism.

For Rouse, the realist's claim that entities exist independently of our practices is identical to the claim that entities are objects existing independently of subjects. The subject-object schema presupposed in this claim introduces an intractable problem concerning knowledge of the "external world" and thereby initiates an endless tug-of-war between realists, who claim that such knowledge is possible, and antirealists, who claim that it is not. Rouse's practical hermeneutics drops to one level below this troublesome schema, operating instead with the more basic Heideggerian concepts of Dasein and world. The tension between realism and antirealism is resolved in Dasein's basic state of Being-in-the-world.

I have shown that the Rouse's hermeneutical solution to the shared confusion of realism and antirealism includes an assimilation of existence to meaning. Following what he takes to be the pragmatism of Being and Time, Rouse construes entities as such in terms of equipment and argues that any specific item of equipment can only be what it is within an overall equipmental totality. Heidegger describes this equipmental totality as constituting the structure of the world. Only through their disclosure within the practical structure of an equipmental world do entities have meaning, which for Rouse means that only then can they exist. According to Rouse, we can never get at the real as something which exists independently of our interpretations.

In the next section, I will argue that Rouse's assimilation of existence to meaning faces significant difficulties. In the section following that one, I will then argue that these difficulties emerge at the exact point where Rouse parts company with Heidegger. The final conclusion towards which I am aiming is that Heidegger can succeed where Rouse fails precisely because Heidegger does not assimilate existence to meaning. He allows, as Rouse does not, that it is possible to get at the real as something which exists independently of our interpretations. Thus, Heidegger can be construed as a minimal kind of realist after all. ${ }^{8}$

8. There is a lively and wide-ranging debate in the literature over the question of Heidegger's realism. Alas, to discuss it would carry me well beyond the narrow focus of this essay. I refer the reader to the following texts: Blattner (1994, 2004); Bourgeois \& Rosenthal (1988); Cerbone (1995, 2005); Dreyfus (1991, 2001); Dreyfus \& Spinosa (1999); Hoffman (2000); Leung (2006); Schatzki (1992); Stepanich (1991); Tanzer (1995, 1998); and Tiez (1993). Glazebrook (2001a) brings much of this debate into conversation with recent work in the philosophy of science. 


\section{Rouse as Confused Realist}

Rouse's conviction that nothing exists without meaning is clearly presented in the following two passages:

[W] hat exists depends upon the field of meaningful interaction and interpretation within which things can be encountered. (Rouse 1987, p. 160.)

There cannot be things that cannot interact with the things disclosed within a meaningful world [. . .]. (Rouse 1987, p. 160.)

Yet Rouse's own language immediately betrays this conviction, and he ends up equating meaning, not with existence, but with manifestation, or "showing."

[T]he possible ways a thing can be depends upon the configuration of practices within which they become manifest [. . .]. (Rouse 1987, pp. 160-161.)

This configuration of practices [. . . ] allows things to show themselves as they are in a variety of respects. (Rouse 1987, p. 160.)

This slide from existence to manifestation points up a serious conceptual difficulty in Rouse's practical hermeneutics of science. The nub of the problem is an equivocation in his use of the word "thing." In the first pair of statements, "thing" refers to an entity which exists only within a world of meaning. In the second pair, "thing" refers to an entity whose ways of appearing are constrained by such a world, but whose existence is not. The impression in the latter case is of an entity lurking somewhere behind the scenes, awaiting its cue to leap out onto the world stage. Manifestation thus seems to presuppose existence. Rouse further reinforces this impression in one final statement.

[F]or there to be things of any particular kinds, there must be a world to which they belong. (Rouse 1987, p. 160.)

Here the argument is no longer that the existence of things entails their participation in a world of meaning, but rather that their being entities of some particular kind, that is, their possession of determinate properties, entails such participation. So, it looks like Rouse, contrary to his own claims, admits that entities do exist independently of a meaningful world after all. It is just that the nature of these worldless entities remains undetermined, that is to say, they escape definition. Rouse's attempt to assimilate existence to meaning is betrayed by the very language in which he describes that assimilation. 
The same difficulty can also be found in Rouse's discussion of a specific case study from biochemistry. The case involves what biochemists eventually came to recognise as thyrotropin releasing hormone, or TRH. Rouse (1987, p. 163) writes that the name "TRH" was originally used to designate "whatever was physiologically active $[\ldots]$ in certain chromatographically isolated fractions of the hypothalami of sheep or pigs." He notes that, at this early stage, biochemists did not know if TRH denoted "a thing rather than an unstable artifact" (Rouse 1987, p. 163). According to Rouse, the difference between an unstable artefact and a thing is that a chemical structure can be attributed to the latter. Once biochemists succeeded in attributing a chemical structure to what Rouse also refers to as "the stuff in the fractions," that stuff was no longer an unstable artefact but manifest itself as a genuine "substance" (Rouse 1987, p. 163). Hence, Rouse distinguishes between "unstable artefacts" and "stuff," on the one hand, and "things" and "substances," on the other, arguing that only the latter can be properly recognised as candidates for existence. What he refers to as "the complex of practices that had developed over a hundred years of biochemistry" comprise the conditions for the existence of TRH (Rouse 1987, p. 163). Yet it then becomes rather puzzling what the terms "unstable artefact" and "stuff" are meant to refer to if not something which exists. It seems more reasonable to say that the terms refer to something about which we can say that it is but not what it is, because what it is has not yet been determined by the biochemists who have taken it as their object of study.

As a consequence of this tension between Rouse's professed ambitions and his actual achievements, his practical hermeneutics must appear, from the realist's perspective, somewhat confused. On the one hand, Rouse rejects the realist claim that entities exist independently of practice. Thus Rouse looks to be espousing a form of pragmatic antirealism. On the other hand, Rouse's own practical use of language demonstrates his tacit acceptance of the independence claim. Thus Rouse is an antirealist in theory, but a realist in practice. For the realist this is quite enough to declare Rouse a realist, if a somewhat confused one.

Yet this realist response will stick only if the independence claim makes sense. Rouse, however, offers an argument against the intelligibility of the realist's independence claim. He writes that

[t]he realist needs to give some account of understanding such that we can understand how our interpretations take the world to be independent of how the world really is. Otherwise the alleged independence of object and interpretation can never get off the ground. (Rouse 1987, p. 154.) 
If we follow Rouse in taking the realist to claim that entities possess determinate properties independently of our interpretations of them, then Rouse's argument will find traction. However, such a claim goes much further than the more modest claim that entities simply exist independently of our interpretations. Against this latter claim, Rouse's argument spins its wheels. The realist's doctrine of independence does not require that entities possess determinate properties independently of interpretation; it only requires that those entities exist independently of interpretation. Yet, in his argument against independence, Rouse saddles the realist with the stronger of the two claims. For him, the realist "takes as already determined both the way the world is and our understanding of how our interpretations take it to be" (Rouse 1987, p. 154). But this is an argument not against the independent existence of entities, but against the independent nature of those entities. This important distinction between an entity's existence and its essence will receive more attention in the next section. For immediate purposes it will be enough to note that Rouse's failure to acknowledge it undermines his argument against the realist's doctrine of independent existence. Hence the charge that Rouse's practical hermeneutics of science is a confused form of realism remains valid.

Unlike Rouse, Heidegger clearly acknowledges a distinction between essence and existence. Indeed, this is what allows him to make the further distinction, mentioned earlier, between reality and the real. Heidegger argues that, for the realist, the term "reality" refers to an ontological construal of the world in terms of objecthood. Under this construal, encounters with the real are determined in advance by a theoretical conception of entities as objects. In other words, according to Heidegger, the realist confuses the brute existence of entities with a theory-laden conception of their objective essence. Hence, the realist is apt to deploy the independence claim as a doctrine which applies to objects rather than more simply to entities.

Heidegger's argument that entities can exist independently of their theoretical interpretation is something with which Rouse would agree. This is just Rouse's argument against theoretical hermeneutics. However, on the basis of a practical hermeneutics, Rouse insists that entities cannot exist independently of their practical interpretation as equipment. In this way, he identifies the existence of an entity with its essence as equipment. This marks his departure from Heidegger. For Heidegger also asserts that entities can exist independently of their equipmental interpretation, indeed, of any interpretation at all. He argues, in other words, that entities can exist without any attachment whatsoever to Dasein: "the fact that Reality is ontologically grounded in the Being of Dasein, does not signify 
that only when Dasein exists and as long as Dasein exists, can the Real be as that which in itself it is" (Heidegger 1962, p. 255 [212]). Moreover, Heidegger is careful to distinguish the existence of an entity from the assertion of its existence.

Of course only as long as Dasein is (that is, only as long as an understanding of Being is ontically [i.e. factually] possible), 'is there' Being. When Dasein does not exist, 'independence' 'is' not either, nor 'is' the 'in-itself'. In such a case this sort of thing can be neither understood nor not understood. In such a case even entities withinthe-world can neither be discovered nor lie hidden. In such a case it cannot be said that entities are, nor can it be said that they are not. But now, as long as there is an understanding of Being and therefore an understanding of presence-at-hand, it can indeed be said that in this case entities will still continue to be. (Heidegger 1962, p. 255 [212].)

Heidegger drives the point home by stating further that "Being (not entities) is dependent upon the understanding of Being; that is to say, Reality (not the Real) is dependent upon [Dasein]" (Heidegger 1962, p. 255 [212]). Like Rouse, Heidegger believes that what an entity is depends on Dasein's understanding. However, unlike Rouse, he also believes that entities have a brute existence independently of such understanding.

The next section will explore this important difference between Rouse and Heidegger in more detail. Meanwhile, it is worth ending this section by emphasising that, in his rejection of realism, Heidegger was specifically concerned with an ambitious form of realism which espouses the strong doctrine that entities possess determinate properties independently of our interpretations of them. Heidegger seems to have taken this specific criticism as grounds for rejecting realism entirely. However, insofar as the more modest doctrine that entities as such exist independently of our interpretations of them provides necessary and sufficient grounds for a minimal realism, I suggest that Heidegger's diagnosis serves less as a recommendation that the realist be dismissed entirely, than it does that she be disabused of the conceptual confusions brought on by her acceptance of the subject-object schema. Once the realist has been so rehabilitated, she can happily claim that we do get at the real as something which exists independently of our interpretations. On this basis, I suggest that Heidegger's early work is able to accommodate and support a minimal form of realism, and, as will be argued in section 6, that this minimal realism provides a solution to the theoretical and practical difficulties debilitating Rouse's practical hermeneutics of science. 


\section{Reclaiming Heidegger from Rouse}

I concluded the last section by pointing up an important difference between Rouse and Heidegger. In this section, I will dwell upon this difference at some length. The reason for doing so has already been alluded to in the previous section. As I hope to demonstrate below, the solution to the problems facing Rouse's practical hermeneutics of science can be found in precisely that part of Heidegger's philosophy from which Rouse works so hard to distinguish himself. Rouse's salvation lies in his reconciliation with Heidegger.

The differences between Rouse and Heidegger turn on two related themes in Heidegger's work, the first general and oblique, the second specific and acute. The first theme forms the very core of Being and Time, and arguably the whole of Heidegger's philosophy, namely, the question of Being. In the opening pages of Being and Time, Heidegger (1962, p. 22 [2]) lists a number of "prejudices and presuppositions which are constantly reimplanting and fostering the belief that an inquiry into Being is unnecessary." One such prejudice is the assumption that the meaning of Being is self-evident. Heidegger notes that

[w]henever one cognizes anything or makes an assertion, whenever one comports oneself towards entities, even towards oneself, some use is made of "Being"; and this expression is held to be intelligible "without further ado" [. . .]. (Heidegger 1962, p. 23 [4].)

Heidegger resists the impulse to treat the meaning of Being as selfevident. One important observation he makes is that the word "being" is polysemic. In The Basic Problems of Phenomenology, a set of lectures he delivered in the summer of 1927, the publication year of Being and Time, Heidegger discerns at least two basic meanings for the term "being": existence and essence. He argues that both existence and essence belong to the Being of an entity. In the case of existence, an entity's being means that it is (Heidegger 1982, p. 120). In the case of essence, an entity's being means how or what it is (op. cit., pp. 120, 218). ${ }^{9}$ Both meanings might ap-

9. Note that in The Basic Problems of Phenomenology Heidegger reworks the traditional distinction between essentia and existentia. This is an example of his method of destructuring the philosophical tradition with the goal, not of transcending its limits, but of releasing its unexpressed positive possibilities. Heidegger (1982, p. 101) claims that the distinction between existence and essence has its roots in the ancient Greek interpretation of entities as "produced." In destructuring the tradition, he argues that this interpretation refers the concepts of existence and essence back to the "intentional structure of the productive mode of comportment" of Dasein (Heidegger 1982, p. 112). In other words, both existence and essence are traditionally rooted in subjectivity. He then argues that existence, construed in terms of "producedness," applies only to entities which exist "within the world," the "world," in his phenomenological view, being internally related to Dasein's un- 
pear in a single case of "being," as in the sentence "X is a tomato." Here the predicate says what $\mathrm{X}$ is and it may also say that it is. ${ }^{10}$ In any case, the question of whether $\mathrm{X}$ is must first be intelligible if the further question of what or how $\mathrm{X}$ is is to make any sense. This is why Heidegger (1982, p. 86) writes that existence is "more original" than essence (cf. Heidegger 1962, pp. 67-68 [42-43]).

In his exposition of Heidegger's philosophy, Rouse scarcely touches on the question of Being, much less the distinction between existence and essence. Indeed, he appears to have entirely overlooked the polysemy of the word "being," taking its meaning to be self-evidently uniform and thus an investigation into its structure unnecessary. For this reason, Rouse's practical hermeneutics of science can be understood as running, in a deep and general sense, very much against the grain of Heidegger's own project. The cost of this difference was tallied in the previous section. Rouse's unsuccessful attempt to assimilate existence to meaning was motivated by his failure to recognise that the Being of entities has two distinct aspects, one existential and the other essential. Thus Rouse mistakes the legitimate identification of an entity's meaning with its essence for the illegitimate identification of its meaning with its existence. In fact, an entity's meaning presupposes the possibility of its existence. In giving short shrift to the question of Being, Rouse denies himself the very analytical resources which could have helped him to stay on track over this difficult conceptual terrain.

The second, more acute, point at which Rouse departs from Heidegger is in his denial of a consequential distinction between everyday practice and scientific theory. Heidegger (1962, p. 412 [360]) models this distinction in terms of a "change-over" from practical circumspection to theoretical discovering. Rouse (1985, p. 203) claims that Heidegger fails to give an account of this change-over, and that he could not possibly have given such an account because the change-over simply never happens. But Rouse

derstanding. Heidegger thus opens a space for entities which may exist "without the world," that is, in the absence of Dasein. For this reason, he can write: "World is only, if, and as long as Dasein exists. Nature can also be when no Dasein exists" (Heidegger 1982, p. 170). As will be argued shortly, Rouse is concerned exclusively with the existence of "products," that is, entities within-the-world, and so he fails to recognise that unproduced entities, entities without-the-world, may exist as well. For a more detailed discussion of Heidegger's destructuring of the traditional distinction between existence and essence, see Bernasconi (1994).

10. I use the subjunctive because the sentence could say what $\mathrm{X}$ is without also asserting the existence of $\mathrm{X}$ (cf. Heidegger 1982, p. 88). For example, X might be a fiction. Note that, in a 1929-30 lecture course, Heidegger draws a similar distinction between "what-being" and "that-being" (Heidegger 1995, p. 332). 
is quite wrong in this regard. In fact, Heidegger does give an account of the change-over. Hence, contrary to Rouse's own claim, Heidegger does indeed advance an argument justifying the distinction between science and everyday practice. Rouse fails to rebut this argument because he erroneously maintains that there is no argument there for him to rebut.

Heidegger (1962, p. 412 [361]) describes the change-over in terms of a modification in the way Dasein understands the Being of entities within the world. This modification moves from an understanding of entities in terms of "readiness-to-hand" to an understanding of them in terms of "presence-at-hand." An entity is understood to be ready-to-hand in virtue of its place within a configuration of practical involvements, that is, an equipmental totality. Hence, ready-to-hand entities are equipmental entities, or equipment. However, it is important to emphasize that they are equipment as it is encountered in use. In its readiness-to-hand, equipment does not stand before us like a football on the shelf of a sporting goods store. Instead, it "withdraws" into, and finds its meaning within, the configuration of practices which constitute its use. As Heidegger writes:

The peculiarity of what is proximally ready-to-hand is that, in its readiness-to-hand, it must, as it were, withdraw [zurückzuziehen] in order to be ready-to-hand quite authentically. That with which our everyday dealings proximally dwell is not the tools themselves [die Werkzenge selbst]. On the contrary, that with which we concern ourselves primarily is the work [. . .]. (Heidegger 1962, p. 99 [69-70])

This point deserves special emphasis because one could mistake the understanding which belongs to the use of equipment for an understanding which thematises such use. In the latter case, equipment becomes the object rather than the vehicle of concern. Heidegger cites economics as a field in which the context of equipment, and the concrete role it plays in Dasein's workaday world, are thematised in this manner. Hence, economics treats ready-to-hand entities as something present-at-hand (Heidegger 1962, pp. 412-413 [361]).

An entity can be understood as present-at-hand only once it has been "released" [entschränkt] from the practical configurations constituting its readiness-to-hand (Heidegger 1962, p. 413 [362]). The change-over from practical involvement to theoretical discovering is an event initiated by an entity's being freed from confinement within a complex of equipmental relations and thereby "discovered" nonequipmentally in terms of presence-at-hand. Coming to understand entities in terms of presence-athand is central to what Heidegger (1962, p. 408 [357]) calls "the ontological genesis of the theoretical attitude," and hence for "the possibility of Dasein's existing in the way of scientific research." 
Heidegger's claim that the discovery of entities present-at-hand lies at the core of theoretical science is the claim against which Rouse (1985, p. 201) musters all of his criticism. He characterises Heidegger's claim as follows.

When discussing the ideal of scientific knowledge [. . .], Heidegger speaks of the "legitimate task of grasping the present-at-hand in its essential unintelligibility" (BT, H324). What is present-at-hand is characterized by this unintelligible brute factuality because it has been decontextualized, deprived of the references to the world of practical activity within which things have a place and make sense. A thing present-at-hand would not belong anywhere or with anything else. What it is is completely defined by its "properties," and it is quite unaffected by its relationship to anything else. (Rouse 1985, pp. 201-202)

There are two points to be made about this passage. First, Rouse's description of entities present-at-hand appears confused. In the second sentence, he refers to them as unintelligible. In the fourth sentence, he says they can be defined by their properties. But surely an entity which can be defined by its properties is not unintelligible. Second, in the passage which Rouse cites from Heidegger, the topic under discussion is not, as Rouse claims, scientific knowledge; it is knowledge as such. ${ }^{11}$ This point is somewhat obscured by the fact that Rouse provides the wrong page number for the passage. ${ }^{12}$ As it happens, the misstep of the second point helps explain the confusion of the first.

The existence of a specifically scientific form of knowledge entails the existence of a more general form of knowledge. Science develops an account of the nature or essence, the definite properties, of the entities with which it concerns itself. Yet, in order to define the essence of an entity, science must first recognise the possibility of its existence. Hence, scientific knowledge of essence presupposes a more basic knowledge of existence. Rouse's failure to distinguish existence and essence is surely near the root of his failure to distinguish the recognition of an entity's brute existence from the scientific articulation of its properties. Yet, Rouse's confusion is just as surely the result of Heidegger's own lack of perspicuity in this matter. In fact, Heidegger refers to entities with scientifically articulated es-

11. The passage refers only to die Erkenntnis, or "knowledge." Half a page earlier, in a different paragraph, Heidegger mentions das wissenschaftliches Erkennen, or "scientific cognition." Macquarrie and Robinson translate the latter phrase as "scientific knowledge," thus losing the sense of das Erkennen as a cognitive process rather than a body of knowledge. Perhaps this infelicity has contributed to Rouse's misunderstanding.

12. Heidegger 1962, pp. 370-372 [324], instead of op. cit., p. 194 [153]. 
sences and entities whose essences remain unintelligible as both being "present-at-hand." Rouse can certainly be forgiven for having been misled by Heidegger's own equivocal and badly managed use of this term.

Joseph Fell (1989) has detected at least four distinct senses for the term "present-at-hand" in Heidegger's early work. Only two of these need worry us here. ${ }^{13}$ In the first case, an entity present-at-hand is encountered following a local breakdown in the practical context wherein an equipmental entity has its meaning (Heidegger 1962, pp. 102-104 [73-74]). For example, my office door is ready-to-hand when there is a key to open it. If, however, I have forgotten my key, the door suddenly loses much of its equipmental significance. If it is Sunday morning, and the administration is absent, then the readiness-to-hand of the door recedes still further. The door becomes ever more useless, a mere obstacle confounding the smooth operation of the practical context in which I find myself. If I have a flight leaving that morning, and my flight tickets and passport are locked in my office, then the door loses entirely its significance as something ready-to-hand. I now encounter it in its brute facticity, a useless thing which just stands there making a mockery of my travel plans. As Heidegger writes, in situations such as these, an entity

reveals itself as something present-at-hand and no more, which cannot be budged without the thing that is missing. The helpless way in which we stand before it [. . . ] uncovers the Being-just-presentat-hand-and-no-more of something ready-to-hand. (Heidegger 1962, p. 103 [73])

The emphasis here is on present-at-hand entities which are unintelligible within the practical configurations structuring our local environment. We still know that they exist, but they no longer make sense.

In the second case, Heidegger uses the term "present-at-hand" to denote those entities which have become the "object" of an assertion or a scientific method. He argues that, as soon as we make an assertion about an entity, a change-over in our understanding of the being of that entity occurs. The ready-to-hand entity with which we were involved now becomes a present-at-hand entity about which we make assertions (Heidegger 1962, p. 200 [158]). Heidegger contrasts this way of being present-athand with the former case. There, the focus was on my office door's "Being-just-present-at-hand-and-no-more." Here, by contrast, Heidegger

13. Of the remaining two senses, the first is an "improper" sense in which all entities, including human beings, are referred to as "present-at-hand" with complete disregard for the other ways in which they might be. The second is a sense in which all referentiality fails and the meaning-world is reduced to unintelligibility (Fell 1989, p. 30). 
argues that the present-at-hand entity, as the object of an assertion, "is given a definite character in its Being-present-at-hand-in-such-and-sucha-manner" (Heidegger 1962, p. 200 [158]). He furthermore writes that

[o]nly now are we given any access to properties or the like. When an assertion has given a definite character to something present-athand, it says something about it as a "what"; and this "what" is drawn from that which is present-at-hand as such. (Heidegger 1962, p. 200 [158])

There is, then, a consequential distinction in Heidegger's work between at least two different ways of being present-at-hand. On the one hand, to say of an entity that it is present-at-hand-and-no-more is just to state the brute fact of its existence. Indeed, very early on in Being and Time, Heidegger (1962, p. 67 [4]) explicitly introduces the term "presence-athand" to denote the existence of entities. ${ }^{14}$ On the other hand, to say of an entity that it is present-at-hand-in-such-and-such-a-manner is to state some fact or facts about its nature or essence. Rouse seems not to have properly understood this structured homonymy in Heidegger's use of the term "present-at-hand." This misunderstanding seriously compromises his claim that the change-over from readiness-to-hand to presence-at-hand simply never happens, and so also his claim that there is no philosophically interesting distinction to be drawn between everyday practice and scientific research.

Heidegger (1962, p. 409 [358]) makes it clear that scientific research is a form of practice, but he does not claim that it is an everyday form of practice. Science aims to articulate the essence of present-at-hand entities, to pick out and describe their most important properties. Hence, on Heidegger's account, science is not concerned with the discovery of the presentat-hand as such, that is, with brute existence. When I stand desperate and discombobulated before my locked office door I am not doing science. Rather, Heidegger (1962, p. 408 [356]) argues that science is concerned with the theoretical discovery of present-at-hand entities within-the-world. As Rouse has so ably argued over so many years, the objects of science are meaningful because scientific research is a way of being-in-the-world. The world of science is configured by regimes of practice, and it is only within this practical context that the objects of science have meaning. On this point, Rouse and Heidegger are in full agreement. But Rouse seems oblivious to this agreement, arguing instead that this is precisely the point at

14. Heidegger reserves the term "existence" exclusively for Dasein. He does this in order to avoid an improper construal of Dasein as a present-at-hand entity with properties, that is, as an object (cf. n. 13). 
which he and Heidegger part company. What has misled Rouse is his false assumption that, for Heidegger, science discovers present-at-hand entities without-the-world rather than within-the-world. In other words, Rouse (1985, p. 203) mistakenly believes that scientific discovery is, on Heidegger's account, the decontextualisation, or "de-worlding," of entities. No doubt Heidegger makes room for present-at-hand entities which have been separated from a world of practical involvement. These are entities which exist, but are without sense. We know that they are, but not what they are. On Heidegger's account, science is in the business of telling us what such entities are, of determining their properties, articulating their essence. Far from a decontextualisation, Heidegger (1962, p. 414 [363]) calls this a process of "thematisation." When thematising a ready-to-hand entity, we look at it "in a new way" as something present-at-hand withinthe-world (Heidegger 1962, p. 412 [361]). ${ }^{15}$ In the process, our understanding of the being of that entity has changed over. We no longer understand it through its immersion in a field of practical involvements, as a fiddler might understand her fiddle while playing it. Instead, our understanding is diverted into a new form which no longer takes the entity as something with which we are involved, but rather as something about which we show our concern (Heidegger 1962, p. 200 [158]). When a fiddle string suddenly breaks, the fiddle is released from its immersion in the practical field of fiddling. The fiddler now has the possibility to direct her attention to the instrument itself rather than to the act of fiddling. Only when an entity has been so released from immersion in a field of practical involvements can science step in and take up that entity as a "theme" for disciplined investigation.

This thematisation amounts to a re-contextualisation of the entity as something one comes to understand through "looking" rather than "using." Heidegger emphasises that looking is also a mode of Dasein's Beingin-the-world, and hence that the entity looked at is still an entity within the world (Heidegger 1962, p. 88 [61]). Rouse mistinterprets Heidegger in this passage as claiming that the change-over from using to looking is "the transition to a decontextualized viewing of the present-at-hand," and that this decontextualised viewing is definitive for theoretical science

15. In his own discussion of the change-over, Robert Brandom (1983, pp. 403-4) argues a similar point: "the move from equipment ready-to-hand [. . .] to objective things present-at-hand, is one not of decontextualization, but of recontextualization. Asserting and the practices of giving and asking for reasons which make it possible are themselves a special sort of practical activity. Responding to something by making an assertion about it is treating it as present-at-hand." As I shall argue shortly, this consequential shift in Dasein's way of responding to entities, that is, in its practices, marks a significant change in the essence of those entities. 
(Rouse, 1985, p. 203). According to Rouse, Heidegger treats scientific cognition in terms of traditional epistemology, as the conceptual act of a worldless subject gaining observational access to independently occurring objects.

But this cannot be right. In fact, Heidegger argues that, when Dasein gains understanding of an entity by looking rather than using, "it does not somehow first get out of an inner sphere in which it has been proximally encapsulated, but its primary kind of Being is such that it is always 'outside' alongside entities which it encounters and which belong to a world already discovered" (Heidegger 1962, p. 89 [62]). It turns out, then, that Heidegger's analysis of theoretical cognition fits hand in glove with his deconstruction of the subject-object schema, discussed earlier. He takes the traditional epistemological account of science, which posits a worldless cogito somehow achieving perceptual access to independent objects, and explains it reductively in existential-phenomenological terms as a particular mode of Dasein's Being-in-the-world wherein Dasein holds back from its immersed involvement with an equipmental entity, and instead views that entity as a determinate object. Heidegger's change-over, then, is not from a Dasein-world relation to a subject-object relation, but from Dasein's encountering an entity-in-the-world pragmatically as equipment to encountering it perceptually as an object. Rouse criticises Heidegger for having failed to demonstrate the former transition, when, in fact, it is the latter with which Heidegger is concerned.

This misunderstanding has serious consequences for the way Rouse reads Heidegger's comments, in Being and Time, on the relation between theory and experiment. Heidegger (1962, p. 409 [35]) writes that "[h]olding back from the use of equipment is so far from sheer 'theory' that the kind of circumspection which tarries and 'considers', remains wholly in the grip of the ready-to-hand equipment with which one is concerned. [. . .] [T]heoretical research is not without a praxis of its own." Far from minimising the involvement of practice in scientific theorising, Heidegger places special emphasis on the ways in which experimental techniques and technologies enable scientific research. He lists several examples:

Reading off the measurements which result from an experiment often requires a complicated 'technical' set-up for the experimental design. Observation with a microscope is dependent upon the production of 'preparations'. Archaeological excavation, which precedes any Interpretation of the 'findings', demands manipulations of the grossest kind. But even in the 'most abstract' way of working out problems and establishing what has been obtained, one manipulates 
equipment for writing, for example. (Heidegger 1962, p. 409

[358])

Rouse (1987, p. 76) takes this passage as proof that Heidegger held research practices to be only "associated" with theoretical cognition: "Scientific knowledge on this view is a form of disengaged viewing guided by a theoretical ('mathematical') projection." But clearly Heidegger's examples can be interpreted quite differently. In fact, Heidegger is pointing out the way in which theoretical science depends necessarily on the manipulation of equipment. Rouse seems to have been misled by his misconstrual of Heidegger's notion of mathematical projection as "a single interconnected theory" (Rouse 1987, p. 81), that is, he mistakes it for a kind of conceptual blanket cast by a detached observer over an independently existing world.

Yet Heidegger explicitly distances himself from the definition of science as a conceptual system. ${ }^{16} \mathrm{He}$ does not reject this definition, but argues that it is incomplete and fails to reach "the meaning of science" (Heidegger 1962, p. 32 [11]). Again, the strategy here is to leave the conventional view intact whilst relieving it of its traditional epistemological foundation. Heidegger argues that the conventional, or "logical," view of science as "an interconnection of true propositions" can itself be explained in terms of an "existential conception" which understands science as "a way of existence and thus a mode of Being-in-the-world" (Heidegger 1962, p. 408 [357]). It is at this level that Heidegger's mathematical projection operates. This projection both precedes and enables science as theoretical cognition. Heidegger defines "projection" as constitutive of Dasein's Being-in-the-world, and writes that the projective aspect of Dasein's existence enables it to understand itself in terms of various "possibilities" (Heidegger 1962, p. 185 [145]). When Heidegger turns to a description of the "ontological genesis" of scientific cognition, he thus emphasises "the way in which Nature herself is mathematically projected" (Heidegger 1962, pp. 413-14 [362], italics removed). Within this projection, entities are encountered in terms of constancy, and thus as the possible bearers of

16. For this reason, Heidegger's early view of science is less vulnerable to Donald Davidson's critique of "conceptual systems" than Rouse's interpretation might imply (see Davidson 1984). Given that the job of science is to disclose the essence, or nature, of entities within the world, it would be illegitimate to accuse Heidegger of introducing the sort of scheme-content distinction which concerned Davidson. After all, seen in the light of Heidegger's Dasein-world relation, the essential "content" of science is inseparable from the "scheme" disclosing its meaning. Furthermore, in the case where understanding fails and an entity is present merely as brute existence, without essence, meaning or determinate properties, the notion of a conceptual scheme is moot. Herman Philipse (2007) defends Heidegger's early position against the Davidsonian criticism. 
stable properties disclosed a priori as "quantitatively determinable (motion, force, location, and time)" (Heidegger 1962, p. 414 [362]). Heidegger argues that "[o]nly 'in the light' of a Nature which has been projected in this fashion can anything like a 'fact' be found and set up for an experiment regulated and delimited in terms of this projection" (Heidegger 1962, p. 414 [362]). Hence, the propositional content of theoretical knowledge and the skilled methods of experimental practice are equally dependent upon a more basic, pre-propositional mathematical projection, which constitutes Dasein's scientific way of Being-in-the-world.

Once the irregularities in Rouse's interpretation of Heidegger have been smoothed away, it turns out that Heidegger espouses a view of experimental practice which agrees in many respects with Rouse's own. This can be seen by returning to Rouse's discussion of the discovery of TRH. He notes that, in the early stages, biochemists did not know if TRH denoted "a thing rather than an unstable artefact" (Rouse 1987, p. 163). According to Rouse, the difference between an unstable artefact and a "thing" in the biochemical context is that a chemical structure can be attributed to the latter. Once the biochemists had succeeded in attributing a chemical structure to the unstable artefact, it was then manifest as a genuine "substance." Rouse (1987, p. 163) argues that this process could only have been possible within the context of "the complex of practices that had developed over a hundred years of biochemistry."

From Heidegger's perspective, one might say that the unstable artefact which would become TRH had to first be disclosed by the mathematical projection as something with the potential to be stabilised, and hence to possess properties determinable within the laboratory. This process of determination involved the discovery of the entity's chemical structure, clearly a theory-laden attribution, but only within the practice-laden context of biochemistry's material tradition. A point on which Rouse and Heidegger would presumably disagree is the precise relation between theory and practice. Rouse seems intent on effacing the traditional theorypractice distinction by reducing theory to practice. Heidegger's aim, in contrast, is more subtle and perhaps less dogmatic. He wishes to preserve a distinction between theoretical and non-theoretical activity, but he subverts its traditional epistemological basis, construing it instead in existential-ontological terms. He furthermore admits his ensuing puzzlement at where precisely the line between the two might now be drawn: " $[I] \mathrm{t}$ is by no means patent where the ontological boundary between 'theoretical' and 'atheoretical' behaviour really runs!” (Heidegger 1962, p. 409 [358]). But the difficulty of identifying the boundary is not, for Heidegger, sufficient reason to declare that no such boundary exists.

This disagreement is part of a deeper discord between Rouse and Hei- 
degger on the question of what kind of practice is characteristic of scientific research. Rouse argues that Heidegger does not allow that scientific research is itself a form of everyday involvement with things ready-tohand. But this is just the complaint that Heidegger affirms the existence of a change-over in Dasein's understanding of entities, from readiness-tohand to presence-at-hand. Hence, on this point, Rouse appears to be simply begging the question against Heidegger. As far as I can tell, Rouse offers two main arguments against the change-over, neither of which succeeds. First, he alleges that Heidegger merely asserts the existence of, but never describes, the change-over. I trust that the preceding discussion, which has glossed only portions of Heidegger's overall description of the change-over, has cast sufficient doubt on this claim. ${ }^{17}$ Second, he seems to reason that, since science is itself a form of practice, there can be no consequential difference between scientific research and more everyday forms of activity. But this position simply presupposes, rather than establishes, a conception of practice as ontologically homogenous. One role of Heidegger's analysis of the change-over is to give an ontological argument for the phenomenological differences between everyday and scientific forms of life. Rouse makes the mistake of assuming that, because both forms of life involve practical manipulation, they must be on a par ontologically. ${ }^{18} \mathrm{He}$ seems to have overlooked the central point of Heidegger's account of the change-over (perhaps because he believes that this account does not exist). The change-over is not a change from engaged doing to disengaged view-

17. Rouse's claim that Heidegger asserts the existence of, but never explicates, the change-over has been an abiding refrain in his work since 1985. He has written, for example, that "Heidegger never does indicate what makes for this sudden leap to a new way of looking at things" (Rouse 1985, p. 203); that "Heidegger does not describe how the practical tasks of science (experiment, instrumental manipulation, theoretical problem solving and calculation) are connected to the disclosure of things as present-at-hand" (Rouse 1998, p. 324); that "Heidegger merely asserted such a changeover without an adequate phenomenological description of how it occurred" (Rouse 2005a, p. 131); and that "Heidegger merely asserted such a changeover without adequately describing it" (2005b, p. 181). It is intriguing to note that Rouse has not always maintained this position. In 1981, he wrote that "Heidegger has carefully described the various possibilities of equipmental breakdown, and how they affect our understanding of and absorption in the task at hand" (Rouse 1981, p. 276, emphasis added). Of course, equipmental breakdown is central to the change-over. To the best of my knowledge, Rouse has never acknowledged, much less offered an explanation for, this dramatic and consequential early shift in his interpretation of Heidegger. For further analyses of Heidegger's account of the change-over, see Seigfried (1980, passim), Kockelmans (1985, pp. 118-138), Bast (1986, pp. 139-162), McNeill (1999, pp. 72-92), and Schwendtner (2005, pp. 50-86).

18. Hubert Dreyfus (2000, p. 314n.1) expresses his own dissatisfaction with this aspect of Rouse's philosophy when he complains that "Joe, it seems to me, wants to use the fact that all activity is some form of practical coping to level every distinction in sight." 
ing; it is a change in the way we understand the being of those entities we encounter as part of our ongoing involvement in the world. In other words, what changes is the form of understanding within which entities are manipulated and discovered as meaningful.

\section{Rescuing Rouse with Heidegger}

Keeping the distinction between existence and essence front and centre allows us to tidy up the confusions in Rouse's interpretation of Heidegger, and thus to see how Heidegger may help Rouse out of the conceptual difficulties debilitating his practical hermeneutics of science. Heidegger's notion of a change-over in our understanding of the being of entities has everything to do with the essence of those entities, and scarcely anything to do with their existence. Indeed, existence, as such, remains constant through the change-over from readiness-to-hand to presence-at-hand. In other words, these two ontological categories pick out two distinct ways in which an entity, in its brute existence and basic unintelligibility, might acquire meaning. The point is that, throughout this shifting field of significance, the fact that an entity exists remains perfectly stable. My understanding of what it is may change, but the fact that it is does not. The same holds for practices. The fact that practices exist in both everyday and scientific contexts says nothing about their meaning in those respective contexts.

This is a point which Rouse has failed to take from Heidegger. Because he has not properly absorbed Heidegger's distinction between essence and existence, Rouse assumes that the change-over in the essence of practice between everyday and scientific contexts must also affect the existential status of practice. Hence, he misinterprets Heidegger as espousing the implausible view that the role of practice is diminished when everyday concern changes over to scientific discovery. Rouse adds to this unfortunate misinterpretation with another implausible view, that there is no important difference between everyday and scientific ways of understanding the being of entities. A better response would have been to correct his initial misinterpretation and follow Heidegger in arguing that although the existence of practice remains constant between everyday and scientific contexts, the essence of practice in those contexts is importantly different. ${ }^{19}$

19. When Rouse discusses Heidegger's later work, in which the latter undertakes a more concentrated analysis of experimental practice, he can no longer maintain the selfdeception that allows only a diminished place for practice in Heidegger's conception of theoretical discovery. However, rather than revise his interpretation of Being and Time, Rouse argues that Heidegger later gave up altogether on the specificity of science. $\mathrm{He}$ presents the later Heidegger as claiming that "[s]cience is not something ontologically different from everyday practical concerns; it brings before us more clearly what is also hap- 
One cause of Rouse's confusion can likely be traced to Heidegger's equivocal use of the term "present-at-hand." He employs the term in both an existential and an essential sense, and he often leaves the reader to distinguish the two senses solely on the basis of context. As a consequence, Rouse confuses the two, mistaking Heidegger's legitimate claim that scientific objects are present-at-hand within-in-the-world for the illegitimate claim that scientific objects are present-at-hand without-the-world. Perhaps the most unfortunate result of this misunderstanding is Rouse's failure to recognise the coherent possibility that an existentially presentat-hand entity might, on Heidegger's account, be understood as essentially either present-at-hand or ready-to-hand. This is just the insight that, whatever the nature of an entity, in order for it to be a genuine bearer of meaning the possibility of its existence must first be acknowledged. Existence thus underpins essence. Moreover, existence underpins modifications of essence. Hence, the recognition that our understanding of the being of an entity has changed over presupposes the fact of that entity's existence. The existence of the entity remains constant across changes-over in the way it is understood. Put in more complex terms, the existentially present-at-hand entity remains constant across the change-over from its being essentially ready-to-hand to its being essentially present-at-hand. As Rouse's own work demonstrates, without attentive conceptual management, taking special care to distinguish Heidegger's existential and essential uses of the term "present-at-hand," this point may easily go astray, allowing confusion to spring up in its place.

The principle confusion dogging Rouse's practical hermeneutics of science is his elision of meaning and existence. This elision results from Rouse's failure to distinguish essence from existence. For Heidegger, the meaning of an entity belongs to its essence, and its essence is constituted by its participation in a world structured by relations of significance. Entities which do not participate in a world may still exist, but they have no meaning, that is, no essence. Hence, although we can acknowledge that they are, we can say nothing about what they are. Because Rouse does not recognise this distinction, he provides no conceptual space in his practical hermeneutics for entities which exist but have no meaning. In other words, he is unable to accommodate entities which are not already caught up in a meaning-conferring configuration of practices. Yet, as we saw in

pening in our everyday practices" (Rouse 1985, p. 79). Rouse preserves his first misinterpretation of the early Heidegger by forcing a second implausible reading on the later Heidegger. In fact, Heidegger's later philosophy places even more emphasis on the difference between ordinary and scientific practice. For a discussion of this difference, see Glazebrook (2000a, chpt. 2). 
section 4, although Rouse provides no conceptual space for such entities, ordinary norms of intelligibility force him to nevertheless refer to them. This results in an awkward tension in his theory of science, with a specific class of entities being tacitly invoked even though the theory itself denies their possibility.

By adopting Heidegger's distinction between essence and existence, Rouse might resolve this tension. The distinction would provide him with a conceptual space in which to accommodate entities which exist but have no meaning, and hence allow him to coherently refer to entities which are manifest as meaningful only within a configuration of practices. Conceived as existing but without meaning, such entities satisfy the core realist doctrine that the real exists independently of our practices. Moreover, Heidegger's account also allows that we can get at the real as it stands independently of our practices. This just means that we can directly experience such entities, that we can be unproblematically aware that they exist. This does not mean, however, that we can also know what they are. Such knowledge of an entity's essence is manifest only within a configuration of practices. The realist's basic independence claim refers only to existence, not to essence. Against this minimal standard, Heidegger can be counted a realist. I have proposed that Rouse, if he wishes to escape the incoherencies which plague his practical hermeneutics of science, would do well to count himself a realist of this sort too.

This proposal comes, however, with a price. At the end of the previous section, I noted a significant disagreement between Rouse and Heidegger over the ontological homogeneity or heterogeneity of practice. The distinction between existence and essence allows for the claim that the same entity can have a different meaning depending on the configuration of practices in which it is caught up and in which its essence is determined. Once the ontological heterogeneity of practice is admitted, it becomes possible to argue for a consequential difference between everyday and scientific practice, something to which Rouse has consistently expressed much resistance. He has argued for the elimination of any consequential distinction between scientific research and everyday life by emphasising the ways in which scientific practices have become deeply intertwined with broader cultural phenomena (e.g., Rouse 1993, pp. 12-17). He calls up impressive empirical evidence in support of this claim, citing studies which reveal the considerable extent to which science is affected by the pressures of government, industry, the military, and patriarchy. Yet, from the fact that a sharp line cannot be drawn between science and society it does not necessarily follow that no important difference at all exists between the two. Big Science is indeed inextricably bound up with the military-industrial complex and the masculinism of the society which 
produced and continues to sustain it. But that society cannot itself be reduced to militarism, industrialism, or masculinism. The problem here is not so much the distinction between science and everyday life as it is a too-narrow conception of science which ignores its social and political commitments. These commitments might be taken into account without also jettisoning Heidegger's distinction between everyday and scientific practice. Hence, the Heideggerian solution which I have prescribed for Rouse's troubles stands not only to eliminate certain incoherencies now compromising his work, but it would also allow him to accommodate many of the impressive empirical studies of science to which he justifiably pays his respects. In return, all Rouse would need to do is abandon the implausible claim that there is no consequential difference between scientific research and everyday life. This price, it seems to me, is modest, affordable, and perhaps necessary.

\section{Conclusion}

In this essay, I have argued that Rouse's practical hermeneutics of science is debilitated by some not inconsequential tensions. These tensions are manifest most clearly in the conceptual confusion surrounding his stance on realism. However, although Rouse owes much to Heidegger, I have argued that this confusion is not present in Heidegger's own work. Indeed, Heidegger is able to accommodate a minimal form of realism which is sufficient to meet the realist's core demand that entities can exist independently of our beliefs and practices. Hence, Heidegger's philosophy of science preserves the natural intuition that science "gets at the real." I have furthermore argued that Heidegger can help Rouse in resolving the problems burdening his philosophy of scientific practice. This help might, however, only be delivered once certain flaws in Rouse's reading of Heidegger have been exposed and rectified. I have attempted to do just that, and also to indicate and respond to a worry this rehabilitation might produce for the empirical fidelity of Rouse's project. I conclude by suggesting that the flawed nature of Rouse's presentation of Heidegger casts doubt on Rouse's widely received authority as an expositor of Heidegger's philosophy of science. In this essay, I hope to have provided readers with an alternative reading of Heidegger which may aid them in developing a balanced position of their own regarding Heidegger's relevance for contemporary studies of scientific practice.

\section{References}

Alston, William P. 1998. "Empiricism." Pp. 298-303 in Routledge Encyclopedia of Philosophy. Vol. 3. Edited by Edward Craig. London: Routledge. Bast, Rainer A. 1986. Der Wissenschaftsbegriff Martin Heideggers im Zusam- 
menhang seiner Philosophie. Stuttgart-Bad Cannstatt: Frommann-Holzboog Verlag.

Bernasconi, Robert. 1994. "Repetition and Tradition: Heidegger's Destructuring of the Distinction between Essence and Existence in Basic Problems of Phenomenology." Pp. 123-136 in Reading Heidegger from the Start: Essays in His Earliest Thought. Edited by Theodore Kisiel and John van Buren. Albany: SUNY Press.

Blattner, William D. 1994. "Is Heidegger a Kantian Idealist?" Inquiry $37: 185-201$.

—. 2004. "Heidegger's Kantian Idealism Revisited." Inquiry 47:321-337.

Bourgeois, Patrick L., and Sandra B. Rosenthal. 1988. "Heidegger and Peirce: Beyond 'Realism or Idealism'." Southwest Philosophy Review 4:103-110.

Brandom, Robert. 1983. "Heidegger's Categories in Being and Time." Monist 6(3):387-409.

Cerbone, David R. 1995. "World, World-Entry, and Realism in Early Heidegger." Inquiry 38:401-421.

- 2005. "Realism and Truth." Pp. 248-264 in A Companion to Heidegger. Edited by Hubert L. Dreyfus and Mark Wrathall. Oxford: Blackwell.

Davidson, Donald. 1984. "On the Very Idea of a Conceptual Scheme." Pp. 183-198 in his Inquiries into Truth and Interpretation. Oxford: Clarendon Press.

Devitt, Michael. 1984. Realism and Truth. Oxford: Basil Blackwell.

Dreyfus, Hubert L. 1991. "Heidegger's Hermeneutic Realism.” Pp. 2541 in The Interpretive Turn: Philosophy, Science, Culture. Edited by David R. Hiley, James F. Bohman and Richard Shusterman. Ithaca: Cornell University Press.

- 2000. "Responses." Pp. 313-349 in Heidegger, Coping, and Cognitive Science: Essays in Honor of Hubert L. Dreyfus. Vol. 2. Edited by Mark A. Wrathall and Jeff E. Malpas. Cambridge MA: The MIT Press.

— 2001. "How Heidegger Defends the Possibility of a Correspondence Theory of Truth with Respect to the Entities of Natural Science." Pp. 151-162 in The Practice Turn in Contemporary Theory. Edited by Theodore R. Schatzki, Karin Knorr D. Cetina and Eike von Savigny. London: Routledge.

Dreyfus, Hubert L. and Charles Spinosa .1999. "Coping with Things-inThemselves: A Practice-Based Phenomenological Argument for Realism." Inquiry 42:49-78.

Dummett, Michael. 1978. Truth and Other Enigmas. Cambridge MA: Harvard University Press. 
Fell, Joseph P. 1989. "The Familiar and the Strange: On the Limits of Praxis in the Early Heidegger." Pp. 23-41 in Heidegger and Praxis (The Southern Journal of Philosophy 28, Spindel Conference Supplement). Edited by Thomas J. Nenon.

Fine, Arthur. 1986. The Shaky Game: Einstein, Realism and the Quantum Theory, $2^{\text {nd }}$ edition. Chicago: University of Chicago Press.

Glazebrook, Trish. 1998. "Heidegger on the Experiment." Philosophy Today 42:250-261.

- 2000a. Heidegger's Philosophy of Science. New York: Fordham University Press.

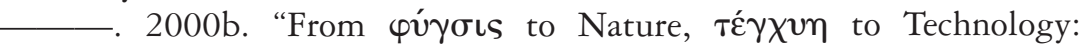
Heidegger on Aristotle, Galileo, and Newton." The Southern Journal of Philosophy 38:95-118.

- 2001a. "Heidegger and Scientific Realism." Continental Philosophy Review 34:361-401.

- 2001b. "The Role of the Beiträge in Heidegger's Critique of Science." Philosophy Today 45:24-32.

Hacking, Ian. 1983. Representing and Intervening. Cambridge: Cambridge University Press.

- 1999. The Social Construction of What? Cambridge MA: Harvard University Press.

Heidegger, Martin. 1962. Being and Time. Translated by John Macquarrie and Edward Robinson. Oxford: Blackwell.

- 1982. The Basic Problems of Phenomenology. Translated by Alfred Hofstadter. Bloomington: Indiana University Press.

- 1995. The Fundamental Concepts of Metaphysics: World, Finitude, Solitude. Translated by William McNeill and Nicholas Walker. Bloomington: Indiana University Press.

Hoffman, Piotr. 2000. "Heidegger and the Problem of Idealism." Inquiry 43:403-412.

Kochan, Jeff. 2008. "Realism, Reliabilism, and the 'Strong Programme' in the Sociology of Scientific Knowledge." International Studies in the Philosophy of Science 22:21-38.

Kockelmans, Joseph J. 1985. Heidegger and Science (Current Continental Research 207). Lanham: The Center for Advanced Research in Phenomenology and The University Press of America.

Leung, Ka-wing. 2006. "Heidegger on the Problem of Reality." The New Yearbook for Phenomenology and Phenomenological Philosophy 6:169-184.

McNeill, William. 1999. The Glance of the Eye: Heidegger, Aristotle, and the Ends of Theory. Albany: SUNY Press.

Philipse, Herman. 2007. "Heidegger's 'Scandal of Philosophy': The Problem of the 'Ding an Sich' in 'Being and Time'." Pp. 168-198 in Tran- 
scendental Heidegger. Edited by Steven Crowell and Jeff Malpas. Stanford: University of Standford Press.

Psillos, Stathis. 1999. Scientific Realism: How Science Tracks the Truth. London: Routledge.

Rouse, Joseph. 1981. "Kuhn, Heidegger, and Scientific Realism." Man and World 14:269-290.

. 1985. "Science and the Theoretical 'Discovery' of the Present-atHand." Pp. 200-210 in Descriptions. Edited by Don Ihde and Hugh J. Silverman. Albany: SUNY Press.

-1987. Knowledge and Power: Toward a Political Philosophy of Science. Ithaca: Cornell University Press.

- 1988. "Arguing for the Natural Ontological Attitude." PSA 1988 1: 294-301.

-1993. "What are Cultural Studies of Scientific Knowledge?" Configurations 1:1-22.

- 1996. Engaging Science: How to Understand Its Practices Philosophically. Ithaca: Cornell University Press.

- 1998. "Heideggerian Philosophy of Science." Pp. 323-327 in Routledge Encyclopedia of Philosophy. Vol. 4. Edited by Edward Craig. London: Routledge.

- 2002a. How Scientific Practices Matter: Reclaiming Philosophical Naturalism. Chicago: University of Chicago Press.

— 2002b. "Vampires: Social Constructivism, Realism, and Other Philosophical Undead." History and Theory 41:60-78.

- 2005a. "Heidegger and Scientific Naturalism." Pp. 123-141 in Continental Philosophy of Science. Edited by Gary Gutting. Oxford: Blackwell.

- 2005b. "Heidegger's Philosophy of Science." Pp. 173-189 in A Companion to Heidegger. Edited by Hubert L. Dreyfus and Mark A. Wrathall. Oxford: Blackwell.

Schatzki, Theodore R. 1992. "Early Heidegger on Being, the Clearing, and Realism." Pp. 81-98 in Heidegger: A Critical Reader. Edited by Hubert L. Dreyfus and Harrison Hall. Oxford: Blackwell.

Schwendtner, Tibor. 2005. Heideggers Wissenschaftsauffassung: Im Spiegel der Schriften 1919-29. Frankfurt am Main: Peter Lang.

Seigfried, Hans. 1980. "Scientific Realism and Phenomenology." Zeitschrift für philosophische Forschung 34:395-404.

Stepanich, Lambert V. 1991. "Heidegger: Between Idealism and Realism." The Harvard Review of Philosophy (Spring):20-28.

Tanzer, Mark Basil. 1995. "Heidegger's Critique of Realism." Southwest Philosophy Review 11:145-159. 
1998. "Heidegger on Realism and Idealism." Journal of Philosophical Research 23:95-111.

Tiez, John. 1993. "Heidegger on Realism and the Correspondence Theory of Truth." Dialogue 32:59-75.

Williams, Michael. 1988. Unnatural Doubts. Oxford: Blackwell.

van Fraassen, Bas. 1980. The Scientific Image. Oxford: Oxford University Press. 